\title{
Historical and current range of the Near Threatened maned wolf Chrysocyon brachyurus in South America
}

\author{
Diego Queirolo, José Roberto Moreira, Lucía Soler, Louise H. Emmons, \\ Flávio H.G. Rodrigues, Andrés A. Pautasso, Joséluis Cartes \\ and VALÉRIA S ALVATORI
}

\begin{abstract}
The Near Threatened maned wolf Chrysocyon brachyurus is a South American endemic canid occurring mainly in grassland-dominated regions. We compiled and mapped recent and historical data to compare the species' present and historical distributions and propose hypotheses for range shifts. There has been recent range expansion in eastern Brazil associated with the deforestation of the Atlantic Forest and conversion of habitat to grasslands for cattle range. The northern, north-eastern and eastern sectors of the species' range have not yet experienced significant modifications, and the species persists in central Brazil, northern and eastern Bolivia, and south-eastern Peru. The largest range contractions have occurred at the species' southern limits but maned wolves are still present in northeastern, central and eastern Argentina, and there are a few records of the species' occurence from Uruguay and northeastern and southern Rio Grande do Sul, southern Brazil. Historically the species occupied nearly all of Rio Grande do Sul, Uruguay and south to at least the 38th parallel in Argentina. The probable causes of the southern range loss are intense anthropogenic pressure combined with limiting abiotic factors such as temperature and humidity. We highlight the need to revise the view of how habitat modifications are influencing the range of $C$. brachyurus so as to improve and coordinate range-wide conservation strategies.
\end{abstract}

Diego Queirolo (Corresponding author) Centro Universitario de Rivera, Universidad de la República, Ituzaingó 667, Rivera, Uruguay. E-mail diqueirolo@yahoo.com.br

José Roberto Moreira Centro Nacional de Pesquisa de Recursos Genéticos e Biotecnologia, Empresa Brasileira de Pesquisa Agropecuária, Brasilia, DF, Brazil

Lucía Soler Cátedra de Fisiología Animal, DBByF, Universidad Nacional del Sur, Bahía Blanca, and Asociación Huellas, Argentina

Louise H. Emmons Smithsonian Institution, National Museum of Natural History, Washington, DC, USA

Flávio H.G. Rodrigues Departamento de Biologia Geral, Universidade Federal de Minas Gerais, Belo Horizonte, MG, Brazil, and Associação para Conservação dos Carnívoros Neotropicais-Pró-Carnívoros, Brazil

Andrés A. Pautasso Área Zoología de Vertebrados, Museo Provincial de Ciencias Naturales 'Florentino Ameghino', Santa Fe, Argentina

José Luis Cartes Asociación Guyra Paraguay, Asunción, Paraguay

Valéria Salvatori Istituto di Ecologia Applicata, Rome, Italy

Received 11 November 2009. Revision requested 25 January 2010. Accepted 9 March 2010.
Keywords Biogeography, canid, Chrysocyon brachyurus, historical distribution, maned wolf, range, South America

\section{Introduction}

The maned wolf Chrysocyon brachyurus is a monotypic L South American endemic that has been recorded almost exclusively in the cerrado, chaco and pampas regions (Cabrera \& Willink, 1973; Langguth, 1975; Dietz, 1985), which are open habitats characterized by grasslands and scrublands with sparse trees, dissected by watercourses bordered by gallery forests. Because of the species' shy behaviour and nocturnal/crepuscular activity there are few records of its distribution in the recent past (Prevosti et al., 2004), and data about its current distribution are scarce (Soler et al., 2005). The historical distribution is known mainly from accounts of 18th and 19th century expeditions (Moreno, 1997), and from data compiled by Casamiquela (1975), Férnandez (1974-1976), Prevosti et al. (2004), Rodden et al (2004) and Chebez (2008).

The present range of $C$. brachyurus is centred on central Brazil, Paraguay and the lowlands of eastern Bolivia (Dietz, 1985; Rumiz \& Sainz, 2002), where the species apparently occurs at relatively high and stable densities (Romero Martínez, 1996; Neris et al., 2002; Rodden et al., 2004). However, in marginal areas of its range, such as northern and north-eastern Argentina, Uruguay and the extreme south of Brazil, densities seem to be low or at least there are few records of the species' occurrence (Beccaceci, 1991; Rumiz \& Sainz, 2002; Indrusiak \& Eizirik, 2003; Rodden et al., 2004). In Argentina single individuals are regularly recorded (Beccaceci, 1993; Jayat et al., 1999; Richard et al., 1999; Pautasso, 2007) but there have been few studies of populations (Soler et al., 2005) either there or in southern Brazil (Indrusiak \& Eizirik, 2003). In Uruguay one individual was captured in 1989 (Mones \& Olazarri, 1990) and a second in 2006 but it is unknown whether a breeding population occurs in the country.

The maned wolf is categorized as Near Threatened on the IUCN Red List (Rodden et al., 2008) and the species is included by most range countries on their own Red Lists of threatened species (DPNyVS \& FMB, 1998; Flores \& Miranda, 2003; Barquez et al., 2006; Chiarello et al., 2008; 
PNUMA, DINAMA \& CLAES, 2008). In 2005 at Serra da Canastra National Park, Minas Gerais, Brazil, the First Maned Wolf International Workshop-Population and Habitat Viability Assessment took place for the purpose of updating the Action Plan for the species throughout its range (CENAP/IBAMA, 2005). Here we evaluate recent changes in the distribution of the maned wolf by (1) compiling records to map its historical distribution, (2) creating a database of recent records, and (3) mapping the species' present distribution.

\section{Methods}

\section{Historical distribution}

We base our historical distribution map on recent palaeontological and historical records, on maps of South American ecoregions and vegetation types, and on our personal knowledge of the species' ecology. To avoid misleading information from Pleistocene-Holocene climate changes (Prevosti et al., 2004) we include only recent (700 years BP) palaeontological data. We reviewed reports from explorers and naturalists from the 16th to early 20 th centuries. Because common name synonyms vary over space and time, historical records need cautious evaluation (Prevosti et al., 2004; Chebez, 2008). For the final compilation of the historical range map we compared the records of C. brachyurus with an ecoregion map of South America (Dinerstein et al., 1995). Because studies on maned wolf ecology show the species to inhabit grasslands and savannah woodlands (Motta-Junior, 200o; Juarez \& Marinho-Filho, 2002; Queirolo \& Motta-Junior, 2007; Rodrigues et al., 2007; Jácomo et al., 2009), we expected its late Holocene distribution to conform to this pattern.

\section{Current distribution}

We created a database of all geo-referenced records of maned wolf presence throughout its range for 1988-2008. Our information sources included captures, photographs, sightings, road kills, museum and zoo records, scientific articles, information from scientists, government reports, interviews and questionnaires. Much relevant knowledge for the range countries has been accumulated in our various field studies during the past 10 years.

In Brazil we sent questionnaires to 1,695 municipalities throughout the country, and gathered information from the scientific literature and from unpublished information acquired from researchers. For Bolivia, data were compiled from museum specimens (Anderson, 1997, and more recent records), observations by scientists, and from interviews with cattle ranchers and reliable informants. The coverage of potential habitat in Bolivia was incomplete, with no data available for large areas of the north-west and far south-east of the Beni savannahs or the south-eastern Pampas del Heath. Records for Paraguay include specimens and data collected by research projects based at the Museo Nacional de Historia Natural del Paraguay (Romero Martínez, 1996) and from observations by inventory projects of Guyra Paraguay (unpubl. data). Neris et al. (2002) interviewed communities about the presence of maned wolves.

In Uruguay the only two records are from specimens in the Museo Nacional de Historia Natural de Montevideo. After publication of the first record in 1990, other reports emerged in different parts of the country but we exclude them from the database as none could be confirmed. For Argentina, we compiled data for the extreme south-west (Santa Fe, Santiago del Estero and Córdoba provinces) from records collected since 1997, including publications, observations of live and dead animals, interviews and questionnaires. These efforts were supported by implementation of the conservation plan for maned wolves in Santa Fe province (Pautasso, 2009). Corrientes and Chaco provinces were surveyed during 2002-2004.

We base the map of current distribution on maps of South American ecoregions, to which we added information about deforestation of the Atlantic Forest from Brazil (SOS Mata Atlântica \& INPE, 2009), Paraguay (provided by Asociación Guyra Paraguay) and Argentina (De Angelo, 2009), and anthropogenic influences in the Brazilian Amazon (from the Brazilian Institute of Geography and Statistics).

\section{Data analysis}

As our work has a continental scale we needed to condense the information from a large database of localities derived from a range of information types of differing reliability. We grouped all location records within $20-\mathrm{km}$ grid cells because some areas included clusters of many points. We evaluated the reliability and repeatability of information within grid cells. After synthesis, our database included 1,149 presence records. A few unexpected records of maned wolf presence remain in the database, mostly from less reliable sources that could not be locally verified.

\section{Results}

\section{Historical distribution}

The historical range map (Fig. 1) is an estimate of the distribution of maned wolves at the time of the European colonization of South America. Maned wolves then occupied, as they do now, almost the entire cerrado of central Brazil from its northern/north-eastern limit with the caatinga, to its north-western limit with Amazonia and its eastern/south-eastern border at the Atlantic Forest.

The southernmost historical limit of the maned wolf possibly reached between the 37th and 39th parallels of 


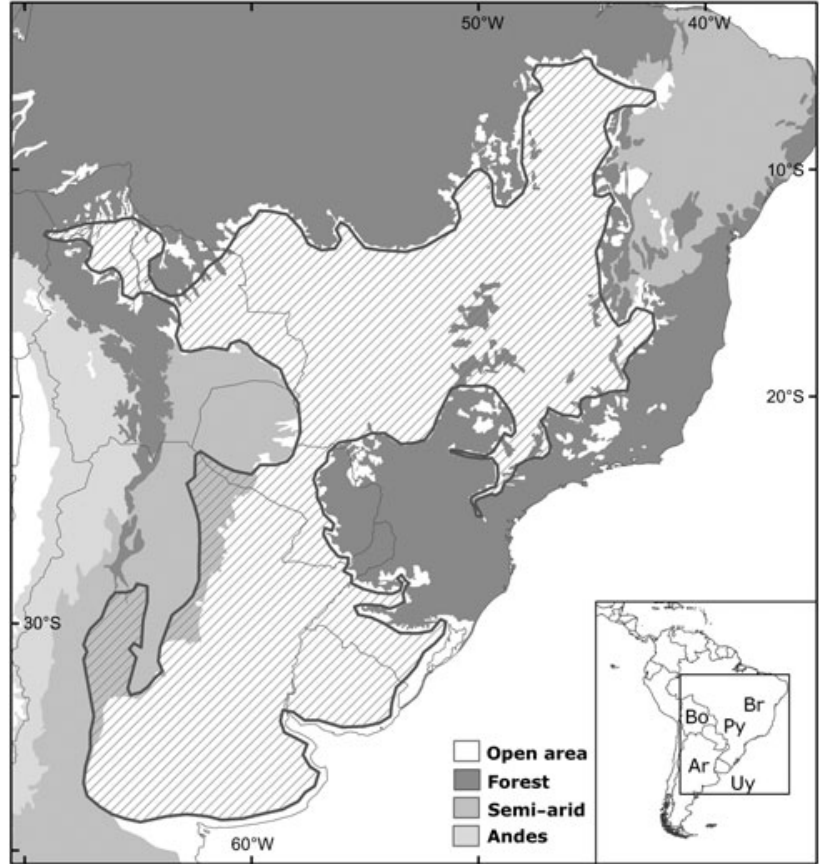

FIG. 1 Historical distribution (diagonal hatched area) of the maned wolf Chrysocyon brachyurus. The rectangle on the inset shows the location of the main map in South America, with two-letter abbreviations of the range countries.

Argentina, and it was present in most of Rio Grande do Sul, Brazil, except on the coast and in some municipalities in the centre and north-west of the state (Breyer, 1979). Maned wolves likewise occupied all of Uruguay.

The western range reached the Beni and Santa Cruz departments of Bolivia and south-east Peru, where it was first collected in 1972 (Hofmann et al., 1976). We have included this part of Peru because it is an extension of the natural savannahs of the Pampas del Heath, although we found no historical records of its presence there.

\section{Present distribution}

The large database of localities contains 1,848 records (Table 1 ), chiefly from interviews and questionnaires (80.6\%). After evaluation the database that we assembled to map the current distribution included 1,149 records. Of 1,695 questionnaires sent to Brazilian City Councils, 707 were answered. We checked unlikely results from these questionnaires either locally, with interviews or by sending new questionnaires. In Argentina 260 (61.0\%) of 429 interviews in Corrientes and Chaco provinces indicated presence of maned wolves. Scientific publications and personal contacts with researchers together provided $15.5 \%$ of the records, and scientific collection and zoo records comprised $3.5 \%$.

The map of the species' current distribution (Fig. 2) resembles the historical map, except for some of the southern, and much of the eastern/south-eastern range. As in the past, maned wolves still occur over a large part of central Brazil where the range is limited to the north and north-west by the forests of Amazonia and to the northeast by the arid caatinga. The map shows an expansion of the species' range in the east and south-east. The western range limits in Bolivia and Peru appear to be the same as the historical range, bounded by Amazonia to the north and by dry chacoan habitat to the south.

The southern distribution of C. brachyurus, where we document large range reductions, crosses the savannahs of the Paraguay River basin into northern and north-eastern Argentina, southern Brazil, and Uruguay. In Argentina the highest concentration of presence records is in large expanses of chaco wetlands, such as those of the Dulce and Salado rivers, where seasonally flooded grasslands predominate, in the provinces of Chaco, eastern Santiago del Estero, north/north-eastern Cordoba, northern Santa $\mathrm{Fe}$, northern Entre Ríos, Corrientes and southern Misiones.

The maned wolf is absent from almost all of Uruguay apart from sporadic occurrences in the north-east, and likewise for the west and south-west of Rio Grande do Sul in Brazil. For these two contiguous areas we lack information to estimate the size or viability of any maned wolf populations. At latitudes greater than $32^{\circ}$ in Argentina the occurrence of the maned wolf is sporadic.

\section{Discussion}

Our maps are the products of diverse information of varying reliability. Nonetheless, the large amount of data, combined with our personal experience and knowledge of the species, which together covers most of its range, lends confidence to our maps. The descriptive data that we collected, despite its subjectivity, was in concordance with the experience and knowledge of all eight authors.

The map of the species' historical range (Fig. 1) indicates a more southerly distribution than that shown by Dietz (1985), who stated that the current range resembled that of the species in 1940, with a southern historical limit in northern Argentina, the Paraguayan chaco and the Brazilian state of Rio Grande do Sul. Records listed by Casamiquela (1975) and Fernández (1974-1976) suggest the former presence of maned wolves in the Argentine provinces of La Pampa, Buenos Aires, Mendoza, San Luis, San Juan and Córdoba. Prevosti et al. (2004) had confidence only in the written records from the wetlands of San Luis, San Juan and Mendoza and in late Holocene fossils from the south of Buenos Aires province $(2,700-3,100$ years BP). Other published distribution maps that could be considered as historical (Langguth, 1970; Dietz, 1985; Ginsberg \& Macdonald, 1990) indicate maned wolves to be present in almost all of north-eastern Brazil (the caatinga). The methods used to create these maps were not provided in the publications and we have not found sources to verify them. 
TABLE 1 The total number of records of the presence of the maned wolf Chrysocyon brachyurus across its range in six South American countries (Fig. 2), by information source, for 1988-2008. After synthesis (see text for details), our database was reduced to 1,149 presence records.

\begin{tabular}{|c|c|c|c|c|c|c|c|c|}
\hline & $\begin{array}{l}\text { Museum } \\
\text { records }\end{array}$ & $\begin{array}{l}\text { Zoo } \\
\text { records }\end{array}$ & $\begin{array}{l}\text { Scientific } \\
\text { articles }\end{array}$ & $\begin{array}{l}\text { Information } \\
\text { from scientists }\end{array}$ & $\begin{array}{l}\text { Government } \\
\text { reports }\end{array}$ & Interviews & Questionnaires & Total \\
\hline Argentina & 16 & 25 & 33 & 66 & & 680 & 65 & 885 \\
\hline Brazil & 10 & & 110 & 7 & 6 & & 707 & 840 \\
\hline Bolivia & & & 8 & 40 & & 18 & & 66 \\
\hline Paraguay & 11 & & 1 & 19 & 1 & 19 & & 51 \\
\hline Peru & & & 2 & 1 & & 1 & & 4 \\
\hline Uruguay & 2 & & & & & & & 2 \\
\hline Total & 39 & 25 & 154 & 133 & 7 & 718 & 772 & 1,848 \\
\hline
\end{tabular}

A persistent problem that adds to the difficulty of validating historical records of presence is the vagary of maned wolf vernacular names (aguará guazú or lobo-guará in much of its range). The common name guará in northeastern Brazil (caatinga and the Atlantic littoral) is used to designate other carnivores such as raccoons Procyon cancrivorus, crab-eating foxes Cerdocyon thous, skunks Conepatus semistriatus, grisons Galictis vittata and kinkajous Potos flavus. This causes ambiguity; for example, in Ceará, Paiva (1973) reported that maned wolves were rare and confined to the south and east of the state. The records seem unreliable because they were based on interviews by undergraduates and displayed much confusion among name synonymies. Paiva's (1973) habitat description for

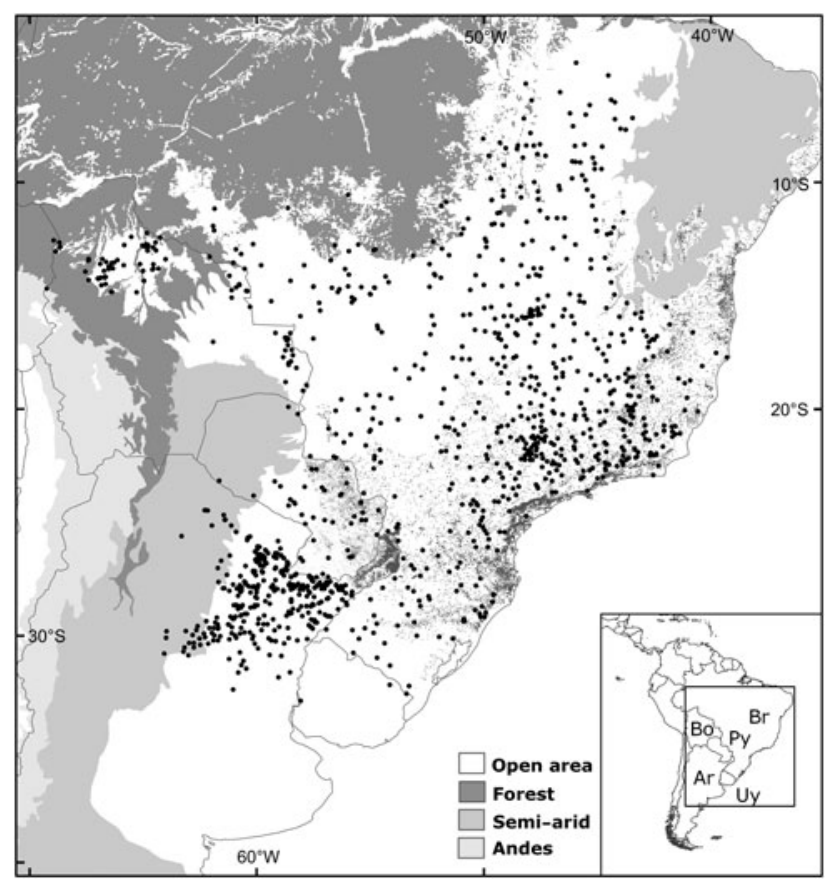

FIG. 2 Present distribution of the maned wolf as indicated by the 1,149 presence records of the species (Table 1) for the period 1988-2008. The rectangle on the inset shows the location of the main map in South America, with two-letter abbreviations of the range countries.
C. brachyurus makes it clear that the species in question was probably $P$. cancrivorus. Our own research, from questionnaires followed by field interviews, indicates that maned wolves were always absent from the entire caatinga, both recently and historically.

Name confusion could likewise explain the suggested presence of maned wolves in some regions of Argentina, especially in Corrientes, or it could account for extralimital records from Amazonia. However, a maned wolf with a global positioning system collar in Bolivia travelled 59 $\mathrm{km}$ in three nights (LHE, unpubl. data) and thus an individual could move hundreds of kilometres in a few weeks. Reliable informants in Bolivia reported sightings of maned wolves on roads in forest $>60 \mathrm{~km}$ from the nearest savannah, and two were shot in farmlands distant from known populations, where local people were unfamiliar with the species (LHE, pers. obs.). These were probably dispersing individuals. Emigrating transients could account for sporadic records of maned wolves in unfavourable habitats outside their usual geographical range.

Our map of the species' present range (Fig. 2) shows key differences from recent maned wolf range maps (Patterson et al., 2003; Rodden et al., 2004). Patterson et al. (2003) presented the same map published by Dietz (1985), which differs from ours mainly in the north-eastern and southern limits. Compared to Rodden et al. (2004) our map expands the distribution to the south and west, through western Paraguay, northern Argentina and southern Brazil. Relative to the historical map our map of present distribution shows a large range reduction across the entire southern range limit, where maned wolves have disappeared from the Argentine provinces of Buenos Aires, La Pampa, San Luis, San Juan, Mendoza, La Rioja and Catamarca, as well as from the southern parts of Córdoba, Santa Fe and Entre Ríos. Recent records from those provinces are mostly from Corrientes, north-central Santa Fe, Chaco, a few departments of Formosa and Entre Ríos and sporadically in Córdoba and Santiago del Estero (Contreras, 1985; Beccaceci, 1993; Richard et al., 1999; Haro et al., 2001; Miatello \& Cobos, 2008; Pautasso, 2008). 
The chief cause of the range contraction of the maned wolf is probably intense anthropogenic pressure from cattle ranching and agriculture in areas that were originally native grassland. Contributing factors could be desertification from land mismanagement, and indiscriminate hunting. All these factors could significantly reduce the numbers of maned wolves, both at their southern limits and in patches throughout the entire range but especially in areas of high human density in the north and north-east of Argentina, Uruguay and southern Brazil (Beccaceci, 1991; Silva, 1994; Richard et al., 1999; Rodden et al., 2004; Soler et al., 2005). The Brazilian cerrado, the centre of the species' range, has had about $50 \%$ of its original vegetation altered by cattle and agro-industry (data compiled in 2009 by the Brazilian Ministry of Environment). Pressure to produce biofuels is likely to accelerate loss of cerrado habitat.

The greatest loss of maned wolf range has been in southern Brazil and Uruguay, which, with the Argentine pampas, are considered the most degraded landscapes in South America (Bilenca \& Miñaro, 2004). Only remnant pockets of habitat in this region may be adequate to support the species, as evidenced by recent records of maned wolves only from the Argentinian pampas of Santa $\mathrm{Fe}$ and Córdoba that are restricted to the vicinity of scarce watercourses and grassland-dominated watersheds. Such patches are generally $1-5 \mathrm{~km}$ wide and $50-100 \mathrm{~km}$ long and hemmed in by fields of soya, corn, sunflower and wheat. Maned wolves appear sporadically in these fragments, where they suffer high mortality from hunting. In Chaco and Corriente provinces maned wolves seemed until recently to have had a wider distribution but large areas have had no reported presence for several decades. A similar situation applies to Uruguay and Rio Grande do Sul, Brazil, where the species also suffers high mortality from hunting, especially when they are animals unknown in the region. Nonetheless, populations through southern Brazil could be connected across a continuum of rural habitats that passes through Santa Catarina to northern Paraná and southern São Paulo, as suggested by Rodden et al. (2004). Such a connection could facilitate the continued presence of individual C. brachyurus in north-eastern Rio Grande do Sul and southern Santa Catarina. It is debatable whether this connection existed historically because it was formerly covered by Atlantic Forest that has now been replaced by open prairies.

The north-western and western parts of the range are apparently the least altered. Kawashima et al. (2007) produced a simulated map of maned wolf potential range and hypothesized a potential expansion into northern Mato Grosso and southern Pará states in Brazil, where vast areas of forest have been converted to livestock pasture. Our data support the possibility of such expansion but there is no current information on the presence of the species in those regions where maned wolves were historically absent.
The north-western edge of the species' range is in a fragment of the Pampas del Heath in Peru that is only accessible by river (Hofmann et al., 1976). Satellite images and overflights show that the Pampas del Heath were originally larger but have become overgrown with forest. They now nearly join with the Beni savannahs, and dispersing maned wolves can currently move between them. This unique, limited savannah has been visited often by researchers for 35 years, and signs of maned wolves are always present. The Peruvian maned wolves are almost certainly maintained by dispersal from a larger population in the Bolivian Pampas del Heath. They are protected, and to preserve the fauna the Peruvian savannah fragments are being maintained and slightly enlarged by prescribed burning (LHE, pers. obs.).

The front of agricultural expansion in Bolivia has mainly involved deforestation of closed-canopy dry forests for cattle and agro-industry (Killeen et al., 2007). There is no evidence that maned wolves have expanded into any of this recently opened habitat, although they occur on cattle ranges in natural grasslands. Cattle ranches newly opened from forest are burned and planted with exotic grasses that may not provide viable habitat for the species. Rural inhabitants generally travel armed for hunting and few large vertebrates of any kind are seen in colonized or densely populated zones. Some native savannahs of Bolivia (Beni savannahs and Pampas del Heath) are subject to seasonal flooding and are unsuitable for industrial crops. They have thus escaped conversion to agriculture although some are now threatened by rice cultivation. Maned wolves are still present in most of the lowland native grassland regions of Bolivia but they appear to be extinct, or nearly so, in the most southerly parts of the Beni savannahs and in the cattle ranges around and to the west of Concepción, Santa Cruz, where human disturbance is greatest. The native savannahs are flood and fire maintained. Without burning they revert to forest. A serious threat to the maned wolf populations in protected areas of Bolivia is habitat loss from failure to maintain the grasslands by burning.

In Paraguay the situation is similar to that in Bolivia. There has been little research but the distribution of maned wolves seems to be associated with traditional cattle ranching on native grasslands, and with other natural savannahs, from open grasslands to scrublands and palmdominated landscapes such as the humid chaco.

The wetlands of the Pantanal include c. $250,000 \mathrm{~km}^{2}$ of Brazil, Paraguay and Bolivia (Willink et al., 2001) in the centre of the maned wolf geographical range. It is the largest seasonally-flooded basin in the world and it undergoes multi-annual hydrological cycles of greater and lesser seasonal inundation. Records of maned wolves are rare in the Brazilian Pantanal and are mainly restricted to the northern borders of the basin (Coutinho et al., 1997). Nonetheless, long-time residents of the region say that 
during the drought years of 1963-1973 maned wolves were common in the south-central regions of the Pantanal but later retreated as inundation increased (Rodrigues et al., 2002). The same seasonal contraction and expansion of flooding occurs in the Bolivian wetlands, where maned wolves can persist as long as there is sufficient dryland to support them from January to May (LHE, pers obs.). On the Paraguayan side of the tri-national boundary the reverse movement may occur, with the species being present on the higher bank of the Paraguay river during high water in the Pantanal (JLC, pers. obs.). Maned wolves may thus adapt facultatively to landscape flooding levels.

In other wetlands, such as the humid chaco of Argentina (Bañados del río Dulce and the Bajos Submeridionales) where there is irregular alternation of wet and dry periods over supra-annual cycles, maned wolves seem to expand during wet cycles and retreat during dry periods, which in extreme cases are associated with high mortality (Miatello \& Cobos, 2008; Pautasso, 2008). Maned wolves are unknown in the Bolivian chaco, where the dry season may be too hot and/or dry.

In contrast to the reduction of the geographic range in some regions, maned wolves have expanded their distribution in eastern and south-eastern Brazil, where Atlantic Forest has been replaced by cattle ranching (Dean, 1996; Capobianco, 2002). There are even a few recent records from coastal Brazil (Silva, 1994; Moreira et al., 1998). Replacement of forests by grasslands and open habitats has favoured the species (Silva, 1994; Motta-Junior, 2000), and recently abandoned farmlands in the first stages of regrowth may be occupied by the species. There is little data on the biology of maned wolves in areas of recent range expansion the omnivorous maned wolf may feed on some cultivated plant species (Motta-Junior, 2000; Motta-Junior et al., 2002; Santos et al., 2003). This expansion demonstrates some adaptability of maned wolves to anthropogenic habitats (Motta-Junior, 200o), a flexibility that can also be seen in cerrado habitats of central Brazil, where the species is commonly seen in altered habitats (Juarez \& Marinho-Filho, 2002; FHGR, unpubl. data).

In conclusion, despite recent range contractions, maned wolves are still present in a large part of their former range. Similar anthropogenic changes have produced range loss in some areas but expansion in others. Clearly there are factors other than land conversion to livestock grazing that influence the persistence or extirpation of maned wolves in a particular region. Climate conditions may be borderline at the caatinga, chaco and pampas fringes of their range, or disease, hunting pressure and high densities of roads may result in unsustainable mortality. We need more data on the impact of anthropogenic habitat alterations on maned wolf behavioural ecology to predict the consequences of specific changes and to design effective conservation strategies for maintenance of the species throughout its range.

\section{Acknowledgements}

In Paraguay we thank María Luisa Ortiz and Marianela Velilla for their dedication in finding and organizing data, Guyra Paraguay for sharing her database on the biodiversity of Paraguay, and Blas Fandiño, Vanina Raimondi and Adriana Senn in Santa Fe, Argentina. LHE thanks the many people who contributed records for Bolivia, especially Mauricio Herrera, Fernando del Aguila, Damian Rúmiz, Alan Hesse, Rob Wallace, Jhonny Ayala, Toa Kyle and Edward Luttwak. Her work in Bolivia is in collaboration with the Museo de Historia Natural Noel Kempff Mercado, Santa Cruz, whose staff and students have been indispensable partners in research on maned wolves. We thank Graziela Dotta for help in the production of the maps and Carlos De Angelo, Oscar Rojas, Leandro Tambosi and Milton Cézar Ribeiro for help in providing information about deforestation of the Atlantic Forest.

\section{References}

Anderson, S. (1997) Mammals of Bolivia; taxonomy and distribution. Bulletin of the American Museum of Natural History, 231, $1-652$.

Barquez, R.M., Díaz, M.M. \& OjedA, R.A. (eds) (2006) Mamíferos de Argentina. Sistemática y distribución. Sociedad Argentina para el Estudio de los Mamíferos, Tucumán, Argentina.

BeCCACECI, M.D. (1991) The maned wolf, Chrysocyon brachyurus, in Argentina. In Internationales Zuchtbuch für den Mähnenwolf, Chrysocyon brachyurus (Illiger, 1811), pp. 50-56. Zoologischer Garten Frankfurt am Main, Frankfurt, Germany.

Beccaceci, M.D. (1993) El Aguará Guazú, Chrysocyon brachyurus, en la provincia de Corrientes. Facena, 10, 19-31.

Bilenca, D. \& Miñaro, F. (2004) Identificación de Áreas Valiosas de Pastizal (AVPs) en las Pampas y Campos de Argentina, Uruguay y Brasil. Fundación Vida Silvestre Argentina, Buenos Aires, Argentina.

Breyer, F.R.S. (1979) O guará no Rio Grande do Sul. Instituto Brasileiro de Desenvolvimento Florestal, Brasília D.F., Brazil.

Cabrera, A.L. \& Willink, A. (1973) Biogeografía de América Latina. Serie Biología, Monografia no. 13. Secretaría General de la Organización de los Estados Americanos, Washington, USA.

Capobianco, J.P.R. (2002) Biomas brasileiros. In Meio Ambiente Brasil: avanços e obstáculos pós-Rio-92 (eds A. Camargo, J.P.R. Capobianco \& J.A.P. de Oliveira), pp. 117-155. Estação Liberdade, Instituto Socioambiental, São Paulo, and Fundação Getúlio Vargas, Rio de Janeiro, Brazil.

Casamiquela, R.M. (1975) Nota sobre la dispersión, en época histórica, de algunos mamíferos en el ámbito pampeanopatagónico. Relaciones de la Sociedad Argentina de Antropología, 9, 111-117.

CENAP/IBAMA (2005) First Maned Wolf (Chrysocyon brachyurus) International Workshop-Population and Habitat Viability Assessment (PHVA): Briefing Book. CENAP/IBAMA, Atibaia, SP, Brazil.

Chebez, J.C. (2008) Aguará guazú Chrysocyon brachyurus (Illiger, 1811). In Los que se van: Mamíferos (ed. J.C. Chevez), pp. 75-83. Editorial Albatros, Buenos Aires, Argentina.

Chiarello, A.G., Aguiar, L.M.S., Cerqueira, R., Melo, F.R., Rodrigues, F.H.G. \& Silva, V.M.F. (2008) Mamíferos. In Livro 
vermelho da fauna brasileira ameaçada de extinção (eds A.B.M. Machado, G.M. Drummond \& A.P. Paglia), pp. 1-203. Fundação Biodiversitas, Belo Horizonte, and Ministério do Meio Ambiente, Brasília D.F., Brazil.

Contreras, A.O. (1985) Algunos comentarios acerca del AguaráGuazú, Chrysocyon brachyurus (Illinger, 1815), en la provincia de Corrientes, Argentina (Mammalia: Carnivora: Canidae). Historia Natural, 5, 119-120.

Coutinho, M.E., Campos, Z.M.S., Mourão, G.M. \& Mauro, R.A. (1997) Aspectos ecológicos dos vertebrados terrestres e semiaquáticos no Pantanal. In Plano de Conservação da Bacia do Alto Paraguai (Pantanal)_PCBAP: Diagnóstico dos meios físicos e bióticos: meio biótico, Vol. 2, pp. 183-322. Ministério do Meio Ambiente, dos Recursos Hídricos e da Amazônia Legal, Brasília, Brasil.

Dean, W. (1996) A ferro e fogo: a história e a devastação da Mata Atlântica brasileira. Companhia das Letras, São Paulo, Brazil.

De Angelo, C. (2009) El paisaje del Bosque Atlántico del Alto Paraná y sus efectos sobre la distribución y estructura poblacional del jaguar (Panthera onca) y el puma (Puma concolor). PhD thesis. Universidad de Buenos Aires, Buenos Aires, Argentina.

Dietz, J.M. (1985) Chrysocyon brachyurus. Mammalian Species, 234, $1-4$.

Dinerstein, E., Olson, D.M., Graham, D.J., Webster, A.L., Primm, S.A., Bookbinder, M.P. \& Ledec, G. (1995) Una evaluación del estado de conservación de las eco-regiones terrestres de América Latina y el Caribe. The World Bank, WWF, Washington, USA.

DPNyVS \& Fmb (1998) Fauna amenazada del Paraguay. Dirección de Parques Nacionales y Vida Silvestre, Fundación Moises Bertoni, Asunción, Paraguay.

Fernández, J. (1974-1976) Modificaciones recientes en el hábitat de algunos mamíferos pampásicos-patagónicos. Implicancias arqueológicas. Anales de Arqueología y Etnología, 29-31, 277-293.

Flores, E. \& Miranda C. (eds) (2003) Fauna amenazada de Bolivia. ¿Animales sin futuro? Ministerio de Desarrollo Sostenible, Proyecto de Fortalecimiento Institucional al MDS (BID 929), La Paz, Bolivia.

GinsberG, J.R. \& Macdonald, D.W. (eds) (1990) Foxes, Wolves, Jackals and Dogs: An Action Plan for the Conservation of Canids. IUCN/ Species Survival Commission Canid Specialist Group and Wolf Specialist Group, Gland, Switzerland.

Haro, J.G., Torres, R.M. \& Bistoni, M.A. (2001) Presencia del aguará guazú Chrysocyon brachyurus en el sistema de humedales Laguna Mar Chiquita-Bañados del Rio Dulce. Facena, 17, 95-98.

Hofmann, R.K., Ponce del Prado, C.F. \& Otte, K.C. (1976) Registro de dos nuevas especies de mamíferos para el Peru, Odocoileus dichotomus (Illiger, 1811) y Chrysocyon brachyurus (Illiger, 1811), con notas sobre su habitat. Revista Forestal del Perú, $5,61-81$.

InDRUsiak, C. \& Eizirik, E. (2003) Carnívoros. In Livro vermelho da fauna ameaçada de extinção no Rio Grande do Sul (eds C.S. Fontana, G.A. Bencke \& R.E. Reis), pp. 507-533. Editora da Pontifícia Universidade Católica do Rio Grande do Sul, Porto Alegre, Brazil.

Jácomo, A.T.A., Kachivakura, C.K., Ferro, C., Furtado, M.M., Astete, S.P., Tôrres, N.M. et al. (2009) Home range and spatial organization of maned wolves in the Brazilian grasslands. Journal of Mammalogy, 90, 150-157.

Jayat, J.P., Barquez, R.M., Díaz, M.M. \& Martínez, P.J. (1999) Aportes al conocimiento de la distribución de los carnívoros del noroeste de Argentina. Mastozoología Neotropical, 6, 15-30.
Juarez, K.M. \& Marinho-Filho J. (2002) Diet, habitat use, and home ranges of sympatric canids in central Brazil. Journal of Mammalogy, 83, 925-933.

Kawashima, R.S., Siqueira, M.F. \& Mantovani, J.E. (2007) Dados do monitoramento da cobertura vegetal por NDVI na modelagem da distribuição geográfica potencial do lobo-guará (Chrysocyon brachyurus). In Annals XIII Simpósio Brasileiro de Sensoriamento Remoto, pp. 3983-3990. Florianópolis, Brazil

Killeen, T.J., Calderon, V., Soria, L., Quezada, B., Steininger, M.K., HA R PE R, G. et al. (2007) Thirty years of land-cover change in Bolivia. Ambio, 36, 600-606.

LANGGUTH, A. (1970) Una nueva classificación de los cánidos sudamericanos. Actas IV Congresso Latinoamericano de Zoologia, 1, 129-143. Caracas, Venezuela.

Langguth, A. (1975) Ecology and evolution in the South American Canids. In The Wild Canids. Their Systematics, Behavioral Ecology and Evolution (ed. M.W. Fox), pp. 192-206. Van Nostrand Reinhold, New York, USA.

Miatello, R. \& Cовоs, V. (2008) Nuevos aportes sobre la distribución del aguará guazú (Chrysocyon brachyurus, Carnivora: Canidae) en las provincias de Córdoba y Santiago del Estero, Argentina. Mastozoología Neotropical, 15, 209-213.

Mones, A. \& Olazarri, J. (1990) Confirmación de la existência de Chrysocyon brachyurus (Illiger) en el Uruguay (Mammalia: Carnivora: Canidae). Comunicaciones Zoológicas del Museo de Historia Natural de Montevideo, XII, 174, 1-6.

Moreira, J.R., Klautau-Guimaräes, N., Pilla, E.J.S., Contel, E.P.B. \& DE BEM, A.R. (1998) Estudo preliminar da variabilidade genética do lobo-guará (Chrysocyon brachyurus). Comunicado Técnico-EMBRAPA, 30, 1-10.

Moreno, F.P. (1997) Viaje a la Patagonia Austral. Ediciones El Elefante Blanco, Buenos Aires, Argentina.

Motta-Junior, J.C. (2000) Variação temporal e seleção de presas na dieta do lobo-guará, Chrysocyon brachyurus (Mammalia: Canidae), na Estação Ecológica de Luiz Antônio, SP. In Estação Ecológica de Jataí (eds J.E. Santos \& J.S.R. Pires), Vol. I, pp. 331346. RIMA Editora, São Carlos, Brazil.

Motta-Junior, J.C., Queirolo, D., Bueno, A.A. \& Belentani, S.C.S. (2002) Fama injusta. Ciência Hoje, 31, 71-73.

Neris, N., Colmán, F., Ovelar, E., Sukigara, N. \& Ishit, N. (2002) Guía de Mamíferos medianos y grandes del Paraguay. Distribución, tendencia poblacional y utilización. SEAM-Agencia de Cooperación Internacional del Japón, Asunción, Paraguay.

Paiva, M.P. (1973) Distribuição e abundância de alguns mamíferos selvagens no estado do Ceará. Ciência e Cultura, 25, $442-450$.

Patterson, B.D., Ceballos, G., Sechrest, W., Tognelli, M.F., B rooks, T., Luna, L. et al. (2003) Digital Distribution Maps of the Mammals of the Western Hemisphere, v. 1.o. NatureServe, Arlington, USA.

Pautasso, A.A. (2007) Mamíferos amenazados o casi amenazados pertenecientes a la colección del Museo Provincial de Ciencias Naturales 'Florentino Ameghino', Santa Fe, Argentina. Mastozoología Neotropical, 14, 85-91

Pautasso, A.A. (2008) Mamíferos de la provincia de Santa Fe, Argentina. Comunicaciones del Museo Provincial de Ciencias Naturales 'Florentino Ameghino', 13, 1-248.

Pautasso, A.A. (ed.) (2009) Estado de conocimiento y conservación del aguará guazú (Chrysocyon brachyurus) en la provincia de Santa Fe, Argentina. Biológica, 11, 1-124.

PNUMA, DINAMA \& CLAES (2008) GEO Uruguay 2008. Informe del estado del ambiente. Programa de Naciones Unidas para el Medio Ambiente, Centro Latino Americano de Ecología Social, Dirección Nacional de Medio Ambiente, Montevideo, Uruguay. 
Prevosti, F.J., Bonomo, M. \& Tonni, E.P. (2004) La distribución de Chrysocyon brachyurus (Illiger, 1811) (Mammalia: Carnivora: Canidae) durante el Holoceno en la Argentina: implicancias paleoambientales. Mastozoología Neotropical, 11, 27-43.

Queirolo, D. \& Motta-Junior, J.C. (2007) Prey availability and diet of Chrysocyon brachyurus in Serra da Canastra National Park, Brazil. Acta Theriologica, 52, 391-402.

Richard, E., Giraudo, A. \& Abdal, C. (1999) Confirmación de la presencia del aguará guazú (Chrysocyon brachyurus, Mammalia: Canidae) en la provincia de Santiago del Estero, Argentina. Acta Zoológica Lilloana, 45, 155-156.

Rodden, M., Rodrigues, F.H.G. \& Bestelmeyer, S. (2004) Maned wolf Chrysocyon brachyurus (Illiger, 1815). In Canids: Foxes, Wolves, Jackals and Dogs. Status Survey and Conservation Action Plan (eds C. Sillero-Zubiri, M. Hoffmann \& D.W. Macdonald), pp. 38-43. IUCN/Species Survival Commission Canid Specialist Group. Gland, Switzerland, \& Cambridge, UK.

Rodden, M., Rodrigues, F.H.G. \& Bestelmeyer, S. (2008) Chrysocyon brachyurus. In IUCN Red List of Threatened Species $v$. 2010.4. Http://www.iucnredlist.org [accessed 6 January 2011].

Rodrigues, F.H.G., Hass, A., Lacerda, A.C.R., Grando, R.L.S.C., B A gno, M.A., Bezerra, A.M.R. \& Silva, W.R. (2007) Feeding habits of the maned wolf (Chrysocyon brachyurus) in the Brazilian cerrado. Mastozoología Neotropical, 14, 37-51.

Rodrigues, F.H.G., Medri, I.M., Tomas, W.M. \& Mourão, G. (2002) Revisão do conhecimento sobre ocorrência e distribuição de Mamíferos do Pantanal. Embrapa Pantanal. Documentos, 38, 1-41.

Romero Martínez, O. (ed.) (1996) Colecciones de Flora y Fauna del Museo Nacional de Historia Natural del Paraguay. MAG/ SSERNMA/DPNVS/MNHNP, Asunción, Paraguay.

Rumiz, D. \& SAinz, L.A. (2002) Estimación del hábitat útil y la abundancia potencial del lobo de crin o borochi (Chrysocyon brachyurus) en Huanchaca, Santa Cruz-Bolivia. Revista Boliviana de Ecología, 11, 3-16.

Santos, E.F., Setz, E.Z.F. \& Gовві, N. (2003) Diet of the maned wolf (Chrysocyon brachyurus) and its role in seed dispersal on a cattle ranch in Brazil. Journal of Zoology, 260, 203-208.

Silva, J.A.S. (1994) Lobo-guará. Chrysocyon brachyurus. In Livro vermelho dos mamíferos brasileiros ameaçados de extinção (eds
G.A.B. Fonseca, A.B. Rylands, C.R.M. Costa, R.B. Machado \& Y.L.R. Leite), pp. 281-288. Fundação Biodiversitas, Belo Horizonte, Brazil.

Soler, L., Carenton, J.M., Birochio, D., Salvatori, V., Orozco, M.M., Rosso, M.S.et al. (2005) Problems and recommendations for the conservation of the maned wolf in Argentina. Endangered Species UPDATE, 22, 3-9.

SOS Mata Atlântica \& INPE (2009) Atlas dos remanescentes florestais da Mata Atlântica, período 2005-2008. SOS Mata Atlântica, Instituto Nacional de Pesquisas Espaciais, São Paulo, Brazil.

Willink, P.W., Sarmiento, J., Chernoff, B., Toledo-Piza, M., Mandelburguer, D. \& Medina, M. (2001) Geographic overview of the Río Paraguay basin, Departamento Alto Paraguay, Paraguay. In A Biological Assessment of the Aquatic Ecosystems of the Río Paraguay Basin, Departamento Alto Paraguay, Paraguay (eds B. Chernoff, P.W. Willink \& J.R. Montambault), pp 80-97. RAP Bulletin of Biological Assessment 19, Conservation International, Washington, USA.

\section{Biographical sketches}

The authors are researching the population dynamics, distribution and conservation status of the maned wolf across its range countries. Diego Queirolo is studying the biogeography of mammal species in the pampas of Uruguay and southern Rio Grande do Sul, Brazil. Flávio H.G. Rodrigues co-coordinates a project for maned wolf conservation in Serra da Canastra National Park in central Brazil. Both are members of the working group for the Action Plan for the Maned Wolf in Brazil. José Roberto Moreira was one of the first to study the genetic variability of the maned wolf in its core range. Lucía Soler and Andrés Pautasso are interested in conservation issues to protect the species in Argentina and are involved on the Conservation Action Plan for the Maned Wolf in Santa Fe province. Louise H. EMmons has been coordinating a project, since 1998, to conserve the maned wolf in Bolivia. José LuIS CARTES is a conservation manager in Paraguay. Valeria Salvatori studies the current and potential distribution of the maned wolf in Argentina. 